\title{
Bathymetry at the Vema Sill
}

\author{
Walter Zenk, ${ }^{*}$ Kevin G. Speer ${ }^{*} \dagger$ and Nelson G. Hogg $\ddagger$ \\ (Received 30 January 1992; in revised form 24 June 1992; accepted 30 June 1992)
}

\begin{abstract}
The Vema Channel represents a prominent location for the northward flow of bottom water in the subtropical western South Atlantic. A recent multibeam echo-sounding survey of the Vema Sill on board F.S. Meteor revealed a narrow and shallow portion of the Vema Channel at $31^{\circ} 12^{\prime} \mathrm{S}, 39^{\circ} 24^{\prime} \mathrm{W}$, the Vema Sill. The survey also showed the remarkably asymmetric shape of the sill region, suggesting an interaction between the bottom flow and the shape of the channel.
\end{abstract}

\section{INTRODUCTION}

INTENSIVE investigations in the subtropical South Atlantic started in late December 1990 as part of the Deep Basin Experiment (DBE), an internationally co-ordinated component of the World Ocean Circulation Experiment (WOCE). The bathymetric and hydrographic work aboard F.S. Meteor partly concentrated on the Vema Channel, from 30 December 1990 to 7 February 1991. Among the objectives of the DBE are: to observe and quantify the deep interior flow away from western boundary currents, to distinguish between boundary and interior mixing processes, and to understand the role of passages in the dynamics and mixing of deep water masses (WCRP12, 1988). Based on these principal DBE goals, Meteor cruise no. 15 included (ZENK and HogG, 1991): the deployment of a joint German-U.S. moored current meter array between the continental slope and the western side of the Rio Grande Rise, a bathymetric survey of the Vema Channel by the Hydrosweep system of the Meteor, and occupation of a highly resolved CTD-section across the sill of the Vema Channel. We discuss here bathymetric observations and related hydrography concerning this prominent location for the interbasin exchange of bottom waters in the South Atlantic.

\section{REVIEW OF THE VEMA BATHYMETRY AND TERMINOLOGY}

The Deutsche Atlantische Expedition 1925-1927 investigated the physics and bathymetry of the entire South Atlantic (SPIESs, 1932). The partition of oceans into systems of basins and ridges had just been accepted, but little detail about the large-scale oceanic bathymetry was known (SUPAN, 1903).

Some of the basins could only be postulated on the basis of large-scale bottom temperature distributions (e.g. Stocks and Wüst, 1935). The use of echo sounders on this

\footnotetext{
*Institut für Meereskunde an der Universität Kiel, 2300 Kiel 1, Germany.

†Present address: Laboratoire de Physique des Océans, IFREMER, 29280 Plouzané, France.

$\ddagger$ Woods Hole Oceanographic Institution, Woods Hole, MA 02543, U.S.A.
} 
initial Meteor-cruise resulted in a rapid increase in the number of soundings (MAURER and STocks, 1933). Six bathymetry charts of the South Atlantic were planned, of which five actually have been published between 1937 and 1961. The last chart no. SI $_{3}$ (STоскs, 1937, 1961 ), includes the present study area. The southeastern segment of this historical map essentially summarizes all bathymetric data at the beginning of modern oceanography.

After World War II considerable efforts from many scientists, especially geologists and geophysicists from Lamont-Doherty Geological Observatory (BEHRMAN, 1969), were devoted to the exploration of the Argentine Basin, and its inlets and outlets, for nearbottom flow (EwING, 1971; Le Pichon et al., 1971). One cruise, VEMA no. 22, was especially dedicated to the investigation of the bathymetry of the Vema Channel and the passage of Antarctic Bottom Water from the Argentine Basin to the Brazil Basin. More recently, significant progress in the hydrography (HoGg et al., 1982) and in paleooceanography (JoHNson et al., 1977) on the Vema Channel has been achieved. The latter study is of particular interest because its chart served as a bathymetric basis for our cruise on the new Meteor. In Fig. 1, a reproduction of 1961 chart by Stocks, we have included frames representing coverage by more recently published (and unpublished) maps.

We summarize the discovery and terminology of the bathymetry at approximately $30^{\circ} \mathrm{S}$, $40^{\circ} \mathrm{W}$ as follows. By the turn of the century, the gross bathymetry had been revealed. Due to large bottom temperature gradients from south to north near $35^{\circ} \mathrm{S}$ a Rio Grande Rise, dividing the Argentine Basin from the Brazil Basin, was postulated as the counterpart to the Walvis Ridge (Supan, 1899, 1903). Old Meteor Stas 43 and 44 on Profile II were coincidently situated on opposite sides of a gap which Captain SPIEss (1932) termed the "Rio Grande Rinne". "Rinne" was later translated by Le PICHON et al. (1971) into "Gap". The reported depths of the two hydrographic stations were 4115 and $3385 \mathrm{~m}$. Two facts are noteworthy. First, the Rio Grande Gap, $150 \mathrm{~km}$ in width, was recognized as a deep northsouth oriented channel dividing the Rio Grande Rise to the east from the Santos Plateau to the west (Heezen and Tharp, 1978). Second, within the gap, the old Meteor detected a narrow valley at sounding no. 11489 , depth $4920 \mathrm{~m}$, at $29^{\circ} 47.1^{\prime} \mathrm{S}$ and $39^{\circ} 27.5^{\prime} \mathrm{W}$. The width of this cut measured less than $30 \mathrm{~km}$. In the literature we found at least four different charts covering the gap between the Rio Grande Rise and the Santos Plateau (Le Pichon et al., 1971; MELGUEN and THIEDE, 1974; Johnson et al., 1977; HoGg et al., 1982). Because of the intensive work done by the Lamont ship Vema the term "Vema Channel" first was suggested by LE Pichon et al. (1971) for the inner deep cut of the Rio Grande Gap.

All available bathymetric charts document a bifurcation just north of the Meteor Profile II (SPIESS, 1932). The $4000 \mathrm{~m}$-isobath splits into an eastern and a secondary, shallower western branch, best depicted in JoHNSON et al.'s (1976) and HoGG et al.'s (1982) charts. A sill depth of $4660 \mathrm{~m}$ was observed at $31^{\circ} 12^{\prime} \mathrm{S}$, $39^{\circ} 24^{\prime} \mathrm{W}$; we call this sill the Vema Sill.

\section{RECENT MEASUREMENTS OF THE VEMA CHANNEL}

While the Vema Sill is the principal sill of the well-surveyed part of the Vema Channel, it may not be the shallowest point of the passage of bottom water from the Argentine Basin to the Brazil Basin along the Vema Channel. According to both the GEBCO (HEEZEN and THARP, 1978) and the recent South Atlantic chart (CHERKIS et al., 1989), the northern end of the Rio Grande Gap between 28 and $29^{\circ} \mathrm{S}$ shoals to a depth shallower than $4400 \mathrm{~m}$, thus isolating the deeper parts of the Vema Channel from the Brazil Basin.

On the other hand, the JoHnson et al. (1976) bathymetry revised by HoGg et al. (1982) 


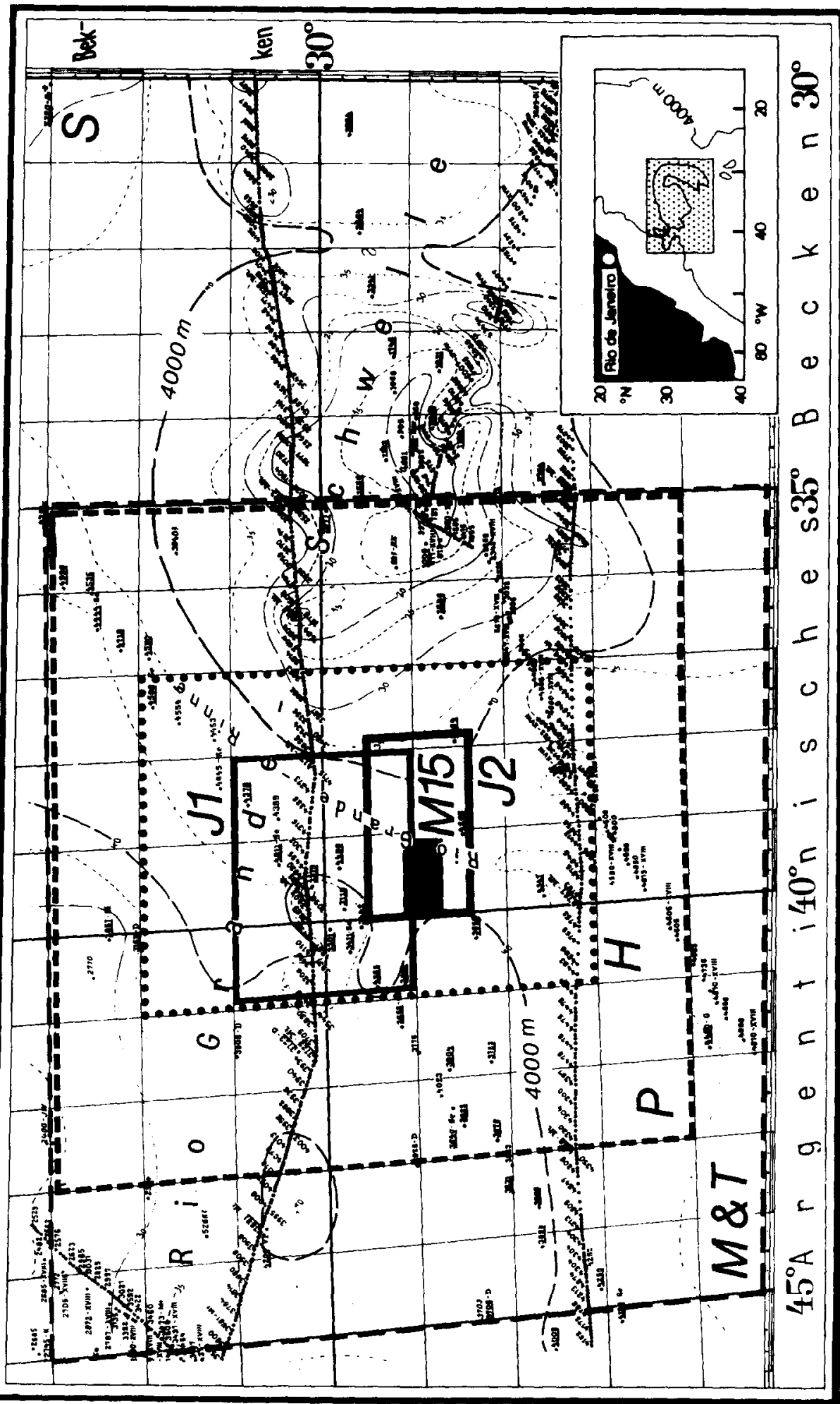

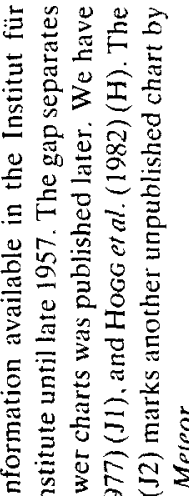

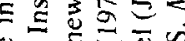

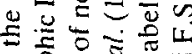

๘ यू

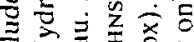

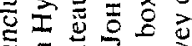
$=$ 焉它总 跣造

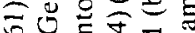

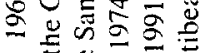
क.

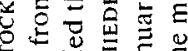
点点焉焉焉 을 事事的

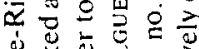

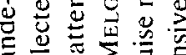

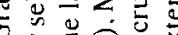
0 至焉市

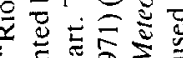
- $20 \sum_{00}$ E E

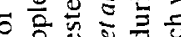

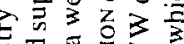
政主 E E

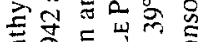

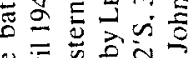
它要过

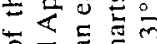
응

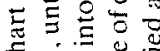
$\overline{0} \dot{0}$

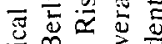
$\infty$ \&

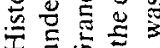
音家 一它芯芯

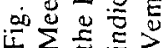




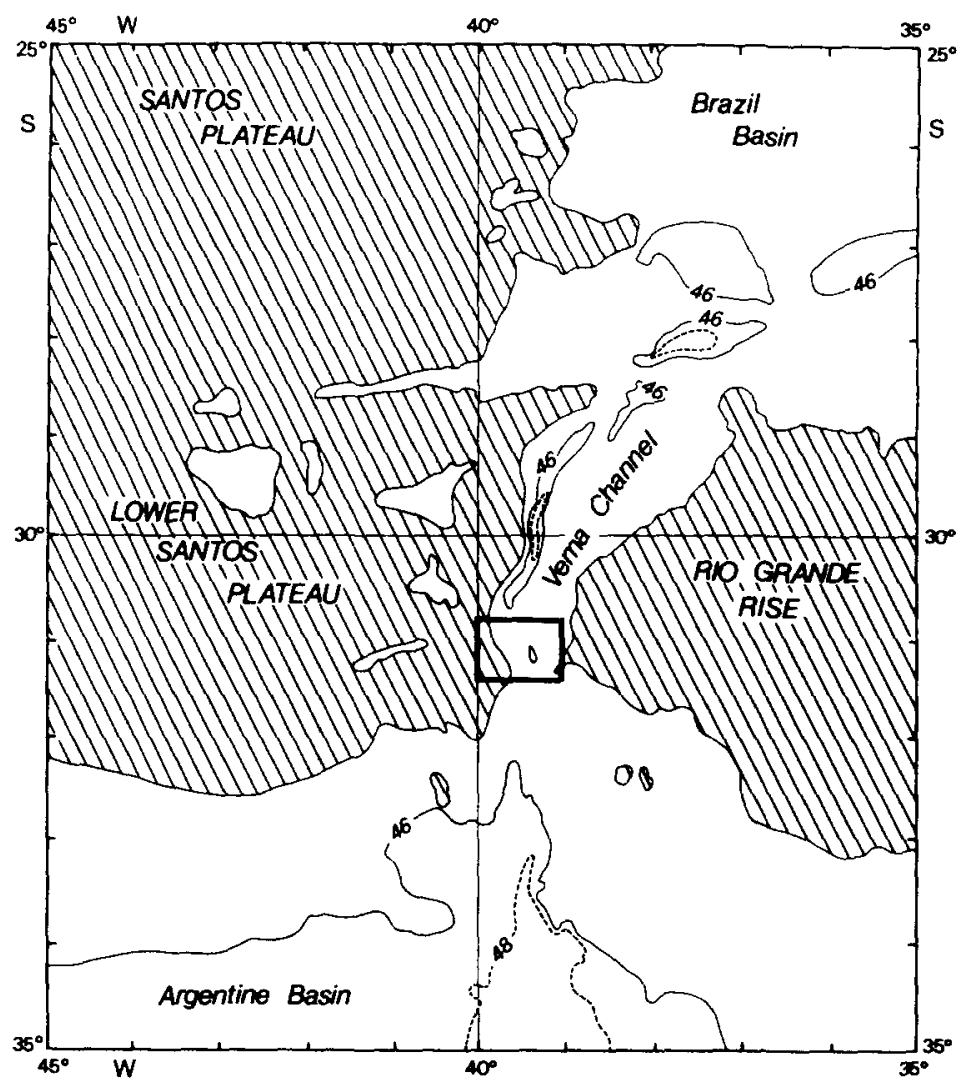

Fig. 2. Selected isobaths from CHERkIs et al. (1989). Depths (hundreds of meters) less than $4000 \mathrm{~m}$ are hatched, $4600 \mathrm{~m}$ (solid) and $4800 \mathrm{~m}$ contour (dashed). The frame at the entrance of the Vema Channel is identical with the M15-box in Fig. 1 and the location of the three-dimensional profile plot in Fig. 3.

shows channel depths greater than $4700 \mathrm{~m}$ continuing north almost to $28^{\circ} \mathrm{S}$. LE PICHON $e t$ al. (1971) show the northern end of the Vema Channel to be controlled at depths greater than $4570 \mathrm{~m}$ at $28.5^{\circ} \mathrm{S}$.

A contouring scheme which opens the Vema Channel at depths greater than $4600 \mathrm{~m}$ between 28 and $29^{\circ} \mathrm{S}$ does appear to be possible, based on the reported bathymetric control of CHERKIS et al. (1989); nevertheless their chart would have the Vema Channel isolated at this depth somewhat farther north, near $27^{\circ} \mathrm{S}$ (Fig. 2). More measurements in this area are clearly needed.

\section{BATHYMETRY OF THE VEMA SILL REGION}

The Vema Sill region surveyed during Meteor 15 is among the narrowest (maybe the narrowest) parts of the Vema Channel. The channel itself has a remarkably well defined

Fig. 3. Three-dimensional surface plot of bathymetry of the Vema Sill region, looking from south to north (downstream). The overlay contains the series of CTD stations which were used for the density section in Fig. 5. 


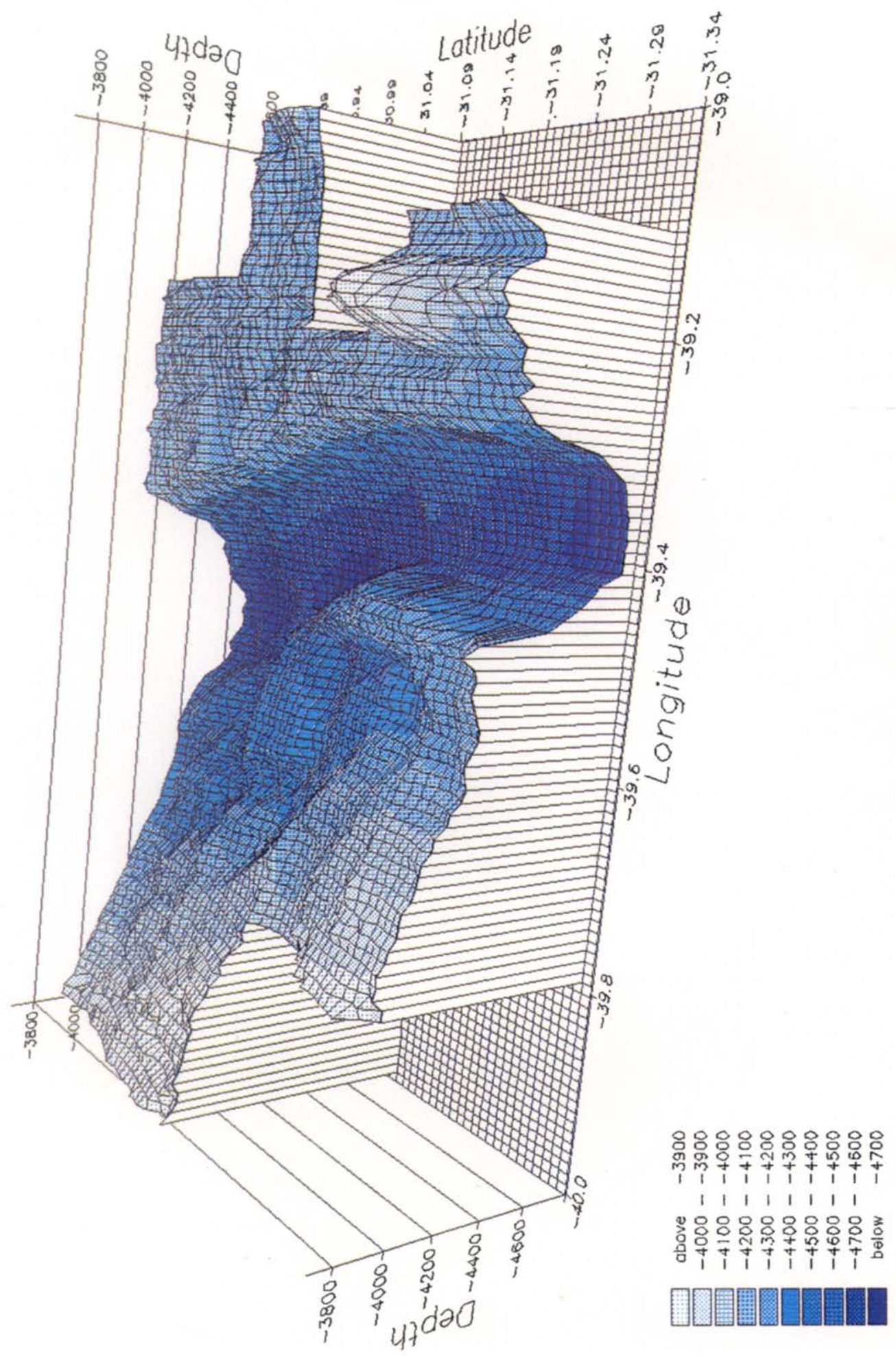





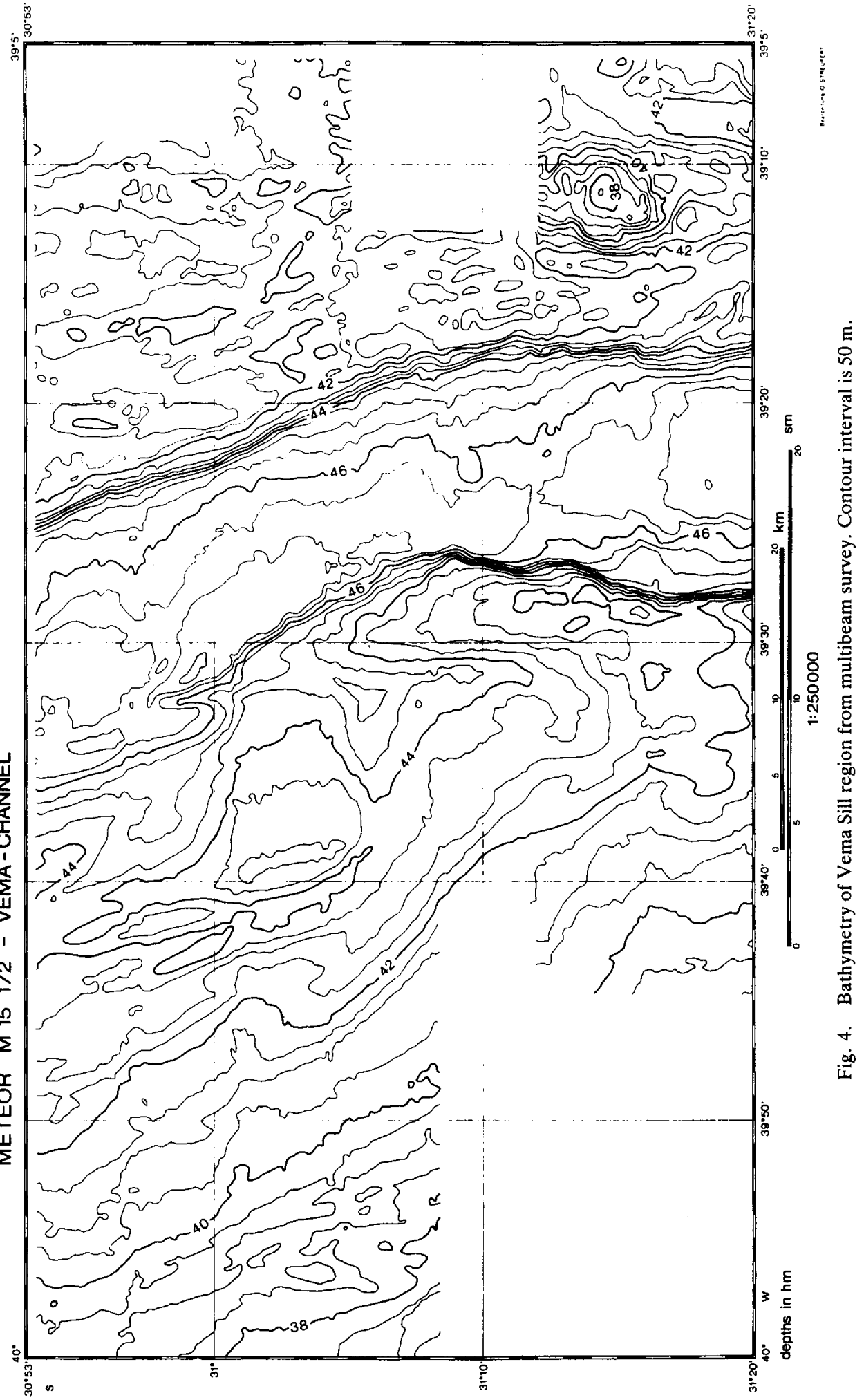




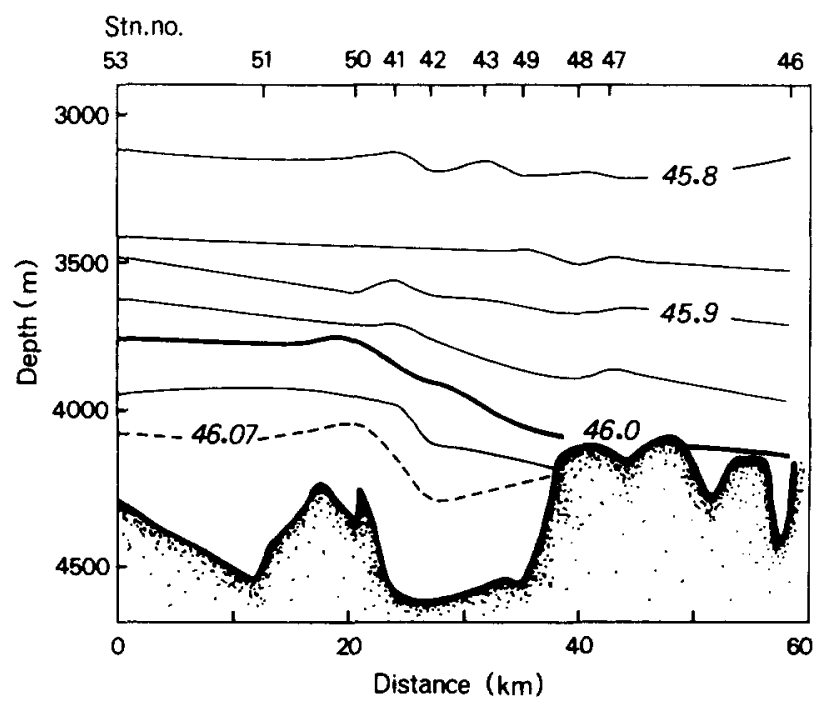

Fig. 5. Density anomaly $\left(\mathrm{kg} \mathrm{m}^{-3}\right)$ referred to $4000 \mathrm{dbar}$ across the Vema Sill. The tendency of the flow to follow isobaths is indicated by the doming of isopycnals near $\mathrm{km} 20$.

form, shown most clearly by a three-dimensional surface plot (Fig. 3). On either side are relatively flat areas which have been called the eastern and western terraces (JoHNSON $e t$ al., 1976).

The bathymetry obtained from the multibeam survey (HYDROSWEEP) shows the exact location of the Vema Sill at $31^{\circ} 12^{\prime} \mathrm{S}, 39^{\circ} 24^{\prime} \mathrm{W}$, and also the surrounding topography (Fig. 4). The western terrace shoals from $4600 \mathrm{~m}$ to less than $3800 \mathrm{~m}$, and is marked by an apparent meander of the channel, which more or less loses its western wall north of $31^{\circ} 05^{\prime} \mathrm{S}$. The existence of a true meander of the flow was confirmed by a CTD survey, which showed that the flow follows isobaths to some extent, turning west and south and then back to the north again (Fig. 5 and see, for example, the $4400 \mathrm{~m}$ isobath, Fig. 4). This valley was not shown on any of the bathymetric studies, although a similar feature was shown just to the north of our survey zone by JoHNSON et al. (1976). Judging from the many stations occupied downstream (HogG et al., 1982), however, this valley does not serve as a significant alternative pathway for bottom water.

A fundamental question that surveys such as this one may help to answer is the nature of the interaction between bathymetry and flow. To what extent is the shape of the channel controlled by flow? The fact that the earth's rotation induces a stronger flow on the western side of the channel may affect the overall shape and meandering through a stronger erosion on this side. An alternative reason for the existence of the western valley could be given by the relationship between this bathymetric feature and the location of the sill itself. Reverse circulations are common in hydraulic solutions downstream of the control sill (HoGG, 1983).

Presently we do not know if the Coriolis force, a hydraulic effect, or random variations in currents and seafloor structures are more important in generating features such as the unnamed valley described above. Nevertheless, there is a clear tendency for the western wall of the Vema Channel to meander, in contrast to the relatively straight eastern side. 
Acknowledgements-We wish to acknowledge the intensive efforts and the help of R. Heygen and C. Heidland. They significantly contributed to the collection and the post-processing of the HYDROSWEEP data set. $\mathrm{J}$. Ulrich recommended some interesting sources in the literature. C. Brückner, O. Streufert and M. Vanicek finished the figures. We further thank Kapitän Bruns and his crew for excellent cooperation on board F.S. Meteor. Financial support was provided by the Deutsche Forschungsgemeinschaft (Si 111/38-1) and the Bundesminster für Forschung und Technologie (3F0535A) and by the National Science Foundation (OCE-9004396). Finally we thank Firma Krupp Atlas Elektronik who contributed to the printing costs. This is WHOI contribution no. 8027.

\section{REFERENCES}

Behrman D. (1969) The new world of the oceans, men and oceanography. Little, Brown and Co., Boston, 436pp.

Cherkis N. Z., H. S. Fleming and J. M. Brozena (1989) Bathymetry of the South Atlantic Ocean, $3^{\circ} \mathrm{S}-40^{\circ} \mathrm{S}$; Geological Society of America, Map and Chart Series-MCH 069.

Ewing M. (1971) Foreword. In: Physics and chemistry of the earth, L. H. Ahrens, F. Press, S. K. Runcorn and H. C. Urey, editors, 8, Pergamon Press, Oxford.

HeEzen B. C. and M. Tharp, scientific coordinators (1978) General Bathymetric Chart of the Oceans (GEBCO), Sheet 5.12. Canadian Hydrographic Service, Ottawa.

Hogg N. G., P. Biscaye, W. Gardner and W. J. Schmirz JR (1982) On the transport and modification of Antarctic Bottom Water in the Vema Channel. Journal of Marine Research, 40 (suppl.), 231-263.

HogG N. G. (1982) Hydraulic control and flow separation in a multi-layered fluid with application to the Vema Channel. Journal of Physical Oceanography. 13, 695-708.

Johnson D. A., S. E. McDowell, L. G. Sullivan and P. E. BisCaYe (1976) Abyssal hydrography, nepholometry, currents, and benthic boundary layer structure in the Vema Channel. Journal of Geophysical Research, 81, 5771-5786.

Johnson D. A., M. Ledbetter and L. H. Burckie (1977) Vema Channel paleo-oceanography: pleistocene dissolution cycles and episodic bottom water flow. Marine Geology, 23, 1-33.

Le Pichon X., M. Ewing and M. Truchan (1971) Sediment transport and distribution in the Argentine Basin, 2, Antarctic bottom current passage into the Brazil Basin. In: Physics and chemistry of the earth, L. H. Ahrens, F. Press, S. K. Runcorn and H. C. Urey, editors, 8, Pergamon Press, Oxford, pp. 29-48.

Maurer H. and T. Stocks (1933) Die Echolotungen des "Meteor", Dt. Atl. Exp. "Meteor" 1925-1927, Bd. 2, $309 \mathrm{pp}$.

MeLguen M. and J. Thiede (1974) Facies distribution and dissolution depths of surface sediment components from the Vema Channel and the Rio Grande Rise (Southwest Atlantic Ocean). Marine Geology, 17, 341353.

Sitess F. (1932) Das Forschungsschiff und seine Reise, Dt. Atl. Exp. "Meteor" 1925-1927, Bd. 1, 442 pp.

Sтосks T. (1937, 1961): Vorläufige Begleitworte zur Grundkarte der ozeanographischen Lotugen 1:5 Millionen. In: Morphologie des Atlantischen Ozeans, Wiss, Erg. Dt. Atl. Exp. "Meteor" 1925-1927, Bd. 3, 1. Teil, 4. Lfg., Bl. S13 was published in 1961.

Stocks T. and G. Wüst (1935) Die Tiefenverhältnisse des offenen Atlantischen Ozeans, Dt. Atl. Exp. "Meteor" 1925-1927, Bd. 3, 1. Teil, 1. Lfg.

Supan A. (1899) Die Bodenformen der Weltmeere, 8, 177-188.

SUPAN A. (1903) Terminologie der wichtigsten unterseeischen Bodenformen, 12, 151-159.

WCRP-12 (1988) WOCE Implementation Plan, 2, WMO, TD Nr. 243.

ZENK W. and N. HoGg (1991) A9 and DBE: Joint German/US work aboard FS METEOR, WOCE Newsletter, $11,10-12$ 